\title{
Corynebacterium pilosum and Corynebacterium cystitidis, Two New Species from Cows
}

\author{
RYO YANAGAWA AND EIICHI HONDA \\ Department of Hygiene and Microbiology, Faculty of Veterinary Medicine, Hokkaido University, \\ Sapporo 060, Japan
}

\begin{abstract}
Two strains of corynebacteria were isolated from cows that showed signs of cystitis and pyelonephritis. According to the results of numerical-analysis and deoxyribonucleic acid homology studies, these strains differed from the known species of Corynebacterium parasitic on or pathogenic to humans and/or other animals. These strains are regarded as belonging to two new species, for which the names $C$. pilosum and $C$. cystitidis are proposed. The type strains of these species are 46 Hara (= ATCC 29592) and 42 Fukuya (= ATCC 29593), respectively.
\end{abstract}

Three organisms, originally described as immunological types (I, II, and III) of Corynebacterium renale (19), were found not to be closely related when tested by deoxyribonucleic acid (DNA) hybridization (8) and, on the basis of a numerical analysis of their phenotypic characters, were found to fall into three different phena (18). Immunological type I (phenon 1) included the reference strain (American Type Culture Collection [ATCC] no. 19412) of C. renale; types II (strain 46 Hara and the strains that were similar to this strain and that belonged to $C$. renale immunological type II) and III (strain 42 Fukuya and the strains that were similar to this strain and that belonged to $C$. renale immunological type III; phena 2 and 3 , respectively) appeared to belong to two new species of the genus Corynebacterium (18). The purpose of this paper is to effect the valid publication of names for these species.

\section{MATERIALS AND METHODS}

Bacterial strains. The strains used in this study are listed in Table 1.

Maintenance of strains. All strains were stored as freeze-dried cultures. Active cultures were maintained on a serum agar consisting of beef infusion $(500 \mathrm{~g}$ of beef muscle infused by heat in 1,000 $\mathrm{ml}$ of water), $1 \%$ peptone (Polypeptone, Daigo Co., Tokyo, Japan), 0.5\% $\mathrm{NaCl}, 1.5 \%$ agar (Shoei Co., Tokyo, Japan), and 5\% calf serum, which was added after sterilizing by filtration through a Toyo 85 SB filter pad (Toyo Roshi Co., Tokyo, Japan).

Media. Serum agar and serum broth were the media basically used. References to the compositions of the various media used for the biochemical and other tests are given below; these media contained $5 \%$ serum (exceptions are indicated in the text). For pigment production, serum agar containing $5 \%$ milk was used.

Biochemical and other tests. The following tests were performed as described by Cowan (1) (method numbers are given in parentheses): oxidation or fer- mentation of glucose; acid from 23 sugars and gas from glucose (serum broth-based sugars were used and were examined for 45 days); nitrate reduction (method 1); nitrite reduction; gelatin liquefaction (method 2); esculin hydrolysis; hippurate hydrolysis; arginine hydrolysis (method 1); starch hydrolysis (method 1); phosphatase test $(\operatorname{method} 1)$; catalase test (method 1$)$; urease activity (method 5) (cells grown on nutrient agar were used for the two latter tests; with Coryne. bacterium pyogenes and C. haemolyticum, however, the cells were grown on serum agar, washed with saline by centrifugation, and then used); oxidase test (method 1); deoxyribonuclease activity (deoxyribonuclease test agar, Eiken Co., Tokyo, Japan, was used); deamination of phenylalanine (method 1); malonate test (method 1); decarboxylase test (arginine, lysine, ornithine) (method 1); decomposition of tyrosine and xanthine; production of indole (method 1), hydrogen sulfide (method 3), and coagulase (method 1); VogesProskauer reaction (method 1); methyl red reaction; casein digestion; coagulation of milk; hemolytic zones around colonies on blood agar (sheep, guinea pig, and rabbit bloods); susceptibility to antibiotics and other antibacterial substances was examined for 7 days (concentrations were expressed as parts per milliliter of serum agar); growth within 7 days on MacConkey agar and Simmons citrate agar; and inhibition of growth within 7 days on serum agar to which was added 6 or $8 \%$ of $\mathrm{NaCl}, 0.1 \%$ of sodium oleate, 2 or $4 \%$ of potassium thiocyanate, $0.04 \%$ of tellurite, $0.05 \%$ of sodium azide, $0.01 \%$ of tryphenyl tetrazolium, $0.01 \%$ of selenite, and $100 \mu \mathrm{g}$ of hydroxylamine hydrochloride per $\mathrm{ml}$; hydrolysis of Tweens $80,60,40$, and 20 ; decomposition of egg yolk protein (clear zones around colonies grown on serum agar with $10 \%$ egg yolk added; examined for 14 days); decomposition of egg yolk lipid (turbid layer formation around colonies grown on serum agar with $10 \%$ egg yolk added; examined for 14 days); lecithovitellin test; salicylate degradation (the test organisms were inoculated on serum agar containing $0.1 \%$ sodium salicylate and incubated at $37^{\circ} \mathrm{C}$; a marked blackening of the medium with growth after 7 days was recorded as a positive reaction); and growth on nutrient agar (without serum). 
Numerical analysis. Analysis of the results obtained with the 17 strains studied was performed by the method of Lessel and Holt (14). C. pyogenes and C. haemolyticum were not used in numerical analysis because they differed profoundly from the other corynebacteria in several ways (15). After calculation of similarity $(S)$ values, the strains were clustered by single linkage in which each strain was admitted to a group at the highest similarity level it had with any other member of that group.

Diagrammatic representation of the grouping of the strains was done by means of a dendrogram (Fig. 1), which made apparent the affinities of the strains and the clusters of strains.

DNA homology test. Nutrient broth was used in the production of labeled cells of strains 46 Hara and 42 Fukuya. Nutrient agar or nutrient agar mixed with calf serum $(10 \%)$ was used in the production of unlabeled bacteria; all cells were grown at $37^{\circ} \mathrm{C}$ for $24 \mathrm{~h}$, with the exception of those of $C$. bovis, C. pyogenes, and $C$. haemolyticum, which were grown at $37^{\circ} \mathrm{C}$ for $48 \mathrm{~h}$.

$\left[{ }^{3} \mathrm{H}\right]$ uridine $(5.0 \mathrm{Ci} / \mathrm{mmol}, 20.6 \mathrm{mCi} / \mathrm{mg}$ ) was purchased from the Radiochemical Centre (Amersham, England). $\left[{ }^{3} \mathrm{H}\right]$ adenine and $\left[{ }^{3} \mathrm{H}\right]$ thymidine were not used because the former was not incorporated into the DNA of $C$. renale to the extent that $\left[{ }^{3} \mathrm{H}\right]$ uridine was, and the latter was not incorporated into the DNA of strain 46 Hara due to the lack of thymidine kinase activity (8).

DNA was extracted and purified by a modified phenol extraction procedure previously described (11). DNA labeled with tritium from $\left[{ }^{3} \mathrm{H}\right]$ uridine was extracted from the cells, which were cultivated for $48 \mathrm{~h}$ in the broth containing $1.5 \mu \mathrm{Ci}$ of $\left[{ }^{3} \mathrm{H}\right]$ uridine per $\mathrm{ml}$. The purified labeled DNA was further treated twice with ribonuclease (EC 2.7.7.16).

Immobilization of DNA on nitrocellulose filters and DNA-DNA hybridizations were performed as described previously (8).

TABLE 1. List of strains included in this study

\begin{tabular}{|c|c|c|}
\hline Species & Source & Designation \\
\hline Corynebacterium bovis & ATCC & 7715 \\
\hline C. cystitidis ........ & Author & $\begin{array}{l}42 \mathrm{Fu}- \\
\text { kuya }^{a}\end{array}$ \\
\hline C. diphtheriae & ATCC & 19409 \\
\hline C. equi . . & ATCC & 6939 \\
\hline C. haemolyticum & ATCC & 9345 \\
\hline C. hoagii . & ATCC & 7005 \\
\hline C. kutscheri & ATCC & 15677 \\
\hline C. murisepticum & ATCC & 21374 \\
\hline C. nephridii .... & ATCC & 11425 \\
\hline C. paurometabolum & ATCC & 8368 \\
\hline C. pilosum ..... & Author & $46 \mathrm{Hara}^{a}$ \\
\hline C. pseudodiphtheriticum & ATCC & 10700 \\
\hline C. pseudotuberculosis & ATCC & 19410 \\
\hline C. pyogenes & ATCC & 19411 \\
\hline C. renale & ATCC & 19412 \\
\hline C. striatum & ATCC & 6949 \\
\hline C. xerosis . & ATCC & 373 \\
\hline
\end{tabular}

${ }^{a}$ Strains 46 Hara and 42 Fukuya were isolated in Hokkaido, Japan, from the urine of cows that showed signs of cystitis and pyelonephritis, respectively.

\section{RESULTS}

Characteristics of strain 46 Hara. Strain 46 Hara contained gram-positive, nonmotile, densely piliated rods, 0.5 by $1.3 \mu \mathrm{m}$, occurring singly, in pairs (angular arrangements), and in masses; club-shaped forms with metachromatic granules also were noted.

Colonies on nutrient agar and on serum agar were cream to pale yellow, entire, circular, opaque, and about $1 \mathrm{~mm}$ in diameter after $24 \mathrm{~h}$ of incubation at $37^{\circ} \mathrm{C}$. No hemolysis was found around surface colonies on blood agar. In broth and in serum broth, a pellicle and a granular sediment were formed, but there was no turbidity.

Aerobic, facultatively anaerobic. Glucose was fermented. In the oxidation-fermentation test, however, change of color was found only when oxidation-fermentation medium with more than $4 \%$ of glucose was used. The biochemical and other characteristics of this strain are summarized in Table 2. The susceptibilities of this strain to various antibiotics and other antibacterial substances are shown in Table 3 .

Characteristics of strain 42 Fukuya. Cultures of strain 42 Fukuya contained gram-positive, nonmotile, piliated, straight to slightly curved rods, 0.5 by $2.6 \mu \mathrm{m}$, often occurring in angular or palisade arrangements. Metachromatic granules were present.

Colonies on nutrient agar and on serum agar were white, entire, circular, semitranslucent, and rather small in diameter, often not readily visible within $24 \mathrm{~h}$ of incubation at $37^{\circ} \mathrm{C}$. In broth cultures, there was slight turbidity but no pellicle.

Aerobic, facultatively anaerobic. Glucose was fermented. The biochemical and other reactions of this strain are summarized in Table 2. The susceptibilities of this strain to various antibiotics and other antibacterial substances are shown in Table 3.

Numerical taxonomic study. Twenty-two characters (acid-fast reaction, motility, crenated colony, growth in serum broth [pH 4.3], gas from glucose, arginine hydrolysis, oxidase test, deoxyribonuclease activity, deamination of phenylalanine, malonate test, decarboxylation of arginine, lysine, and ornithine, coagulation of milk, decomposition of xanthine, production of indole and coagulase, Voges-Proskauer reaction, growth on MacConkey agar and Simmons citrate agar, lecithovitellin test, and degradation of sodium salicylate) which were negative for every strain and seven characters (angular arrangement of cells, Gram strain, raised colony, entire colony, growth at $37^{\circ} \mathrm{C}$, growth in serum broth [pH 7.0], and growth in the presence of amphotericin $\mathrm{B}[100 \mu \mathrm{g}])$ which were positive for every 


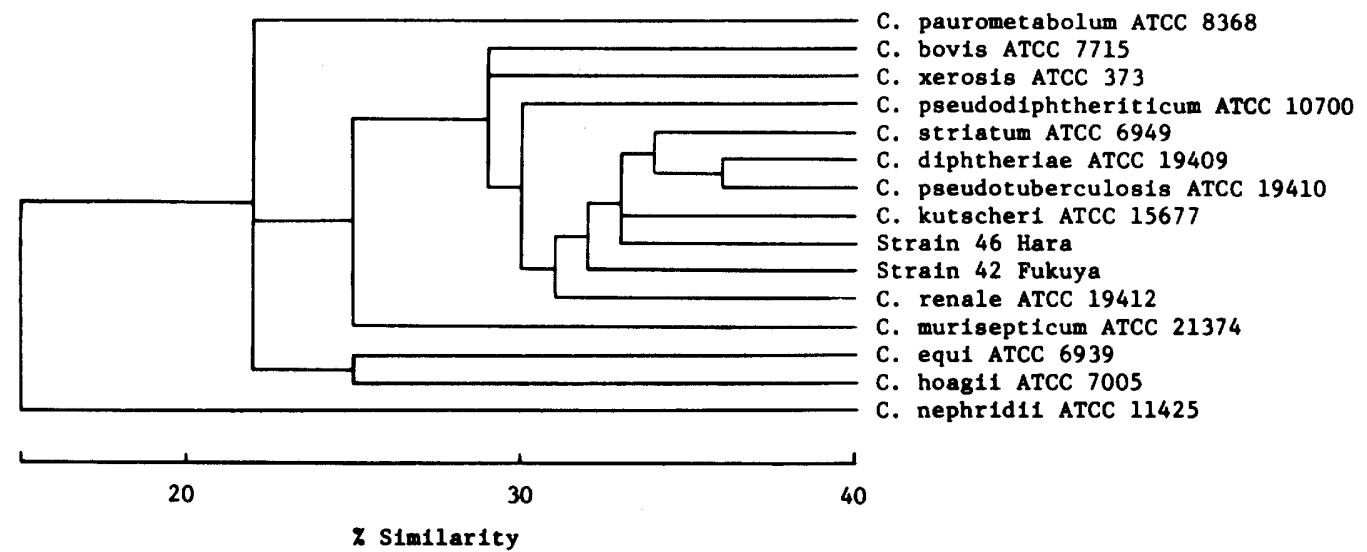

FIG. 1. Dendrogram showing the results of a numerical analysis of the characteristics of strains of Corynebacterium species that are parasitic on or pathogenic to humans and other animals.

TABLE 2. Biochemical and other characteristics of strains 46 Hara and 42 Fukuya

\begin{tabular}{|c|c|c|}
\hline \multirow[b]{2}{*}{ Characteristic } & \multicolumn{2}{|c|}{ Results obtained with: } \\
\hline & Strain 46 Hara & $\begin{array}{c}\text { Strain } 42 \mathrm{Fu}- \\
\text { kuya }\end{array}$ \\
\hline Cell dimensions & $0.5 \times 1.3 \mu \mathrm{m}$ & $0.5 \times 2.6 \mu \mathrm{m}$ \\
\hline \multicolumn{3}{|l|}{ Growth in serum broth at: } \\
\hline$\ldots \ldots \ldots$ & - & - \\
\hline$\ldots \ldots \ldots$ & + & + \\
\hline Heat resistance $\left(56^{\circ} \mathrm{C}\right.$ for $\left.30 \mathrm{~min}\right)$ & + & - \\
\hline Growth at $5^{\circ} \mathrm{C} \ldots \ldots \ldots \ldots$ & - & - \\
\hline$\ldots \ldots \ldots \ldots \ldots \ldots \ldots$ & - & + \\
\hline Catalase and urease $\ldots \ldots \ldots \ldots$ & + & + \\
\hline \multicolumn{3}{|l|}{ Acid from: } \\
\hline Glucose, maltose, dextrin, trehalose, fructose $\ldots \ldots \ldots \ldots \ldots$ & + & + \\
\hline Mannose & + & - \\
\hline Xylose & - & + \\
\hline Rhamnose, galactose, lactose, sucrose & - & - \\
\hline Gas from glucose & - & - \\
\hline Gelatin liquefaction & - & - \\
\hline Nitrate reduction & + & - \\
\hline Hydrolysis of starch and hippurate & + & + \\
\hline Malonate $\ldots \ldots \ldots \ldots \ldots \ldots \ldots$ & - & - \\
\hline Indole, $\mathrm{H}_{2} \mathrm{~S}$, methyl red, acetylmethylcarbinol & - & - \\
\hline 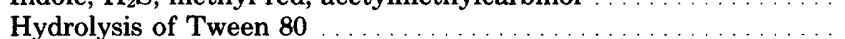 & - & + \\
\hline Phenylalanine deaminase & - & - \\
\hline Decarboxylase test (lysine, arginine, ornithine) $\ldots \ldots \ldots \ldots$ & - & - \\
\hline Caseinase, phosphatase, and oxidase $\ldots \ldots \ldots \ldots$ & - & - \\
\hline
\end{tabular}

strain were not used in the numerical analysis. The remaining 110 characteristics (Table 4) in which there were strain differences were used in the numerical analysis.

The calculated $S$ values of the strains studied (except the strains of $C$. pyogenes and $C$. haemolyticum) are indicated in the dendrogram (Fig. 1) as vertical lines linking the strain stems at the appropriate values.

Thus, strains 46 Hara and 42 Fukuya joined in the dendrogram at 33 and $32 \% S$ values, respectively, with the following strains: $C$. diphtheriae ATCC 19409, C. pseudotuberculosis
ATCC 19410, C. striatum ATCC 6949, and $C$. kutscheri ATCC 15677. C. renale ATCC 19412, C. pseudodiphtheriticum ATCC 10700, C. xerosis ATCC 373, and $C$. bovis ATCC 7715 joined in the dendrogram at $S$ values ranging from 29 to $31 \%$; C. murisepticum ATCC 21374, C. equi ATCC 6939, C. hoagii ATCC 7005, C. paurometabolum ATCC 8368, and C. nephridii ATCC 11425 had much lower similarity values.

DNA homology. The results of the DNA homology determinations are shown in Table 5. Strain 46 Hara had $40 \%$ DNA binding with $C$. renale ATCC 19412 and $60 \%$ with strain 42 
TABlE 3. Susceptibilities of strains 46 Hara and 42 Fukuya to antibiotics and other antibacterial substances

\begin{tabular}{ccc}
\hline \multirow{2}{*}{$\begin{array}{c}\text { Antibiotic or other antibacte- } \\
\text { rial substance }{ }^{a}\end{array}$} & \multicolumn{2}{c}{ Susceptibility $^{b}$ of: } \\
\cline { 2 - 3 } & $\begin{array}{c}\text { Strain 46 } \\
\text { Hara }\end{array}$ & $\begin{array}{c}\text { Strain 42 Fu- } \\
\text { kuya }\end{array}$ \\
\hline
\end{tabular}

Penicillin (1 U)

Streptomycin $(2.5 \mu \mathrm{g}) \ldots \ldots \ldots$

Kanamycin $(10 \mu \mathrm{g}) \ldots \ldots \ldots+$

Terramycin $(10 \mu \mathrm{g})$

Chlortetracycline $(100 \mu \mathrm{g})$

Tetracycline $(1 \mu \mathrm{g})$

Erythromycin $(0.02 \mu \mathrm{g})$

Neomycin $(2 \mu \mathrm{g})$

Oleandomycin $(0.2 \mu \mathrm{g})$

Bacitracin $(1 \mu \mathrm{g})$

Polymyxin B (500 U)

Nalidixic acid $(100 \mu \mathrm{g})$

Amphotericin B $(100 \mu \mathrm{g})$

Pyrimethamine $(25 \mu \mathrm{g})$

Nitrofurazone $(50 \mu \mathrm{g})$

Methyl violet $(0.0005 \%)$

Acriflavine (0.0002\%)

Thionine $(0.02 \%)$

Pyronine $(0.00002 \%)$

Basic fuchsin $(0.002 \%)$

$\mathrm{NaCl}(8 \%)$

Sodium oleate $(0.1 \%)$

Potassium thiocyanate $(4 \%)$

Tellurite $(0.04 \%)$

Sodium azide $(0.05 \%)$

Triphenyl tetrazolium $(0.01 \%)$

Selenite $(0.01 \%)$

${ }^{a}$ Nutrient agar containing $5 \%$ calf serum was used as the basal medium.

${ }^{b}$ Symbols: +, susceptible; -, resistant.

Fukuya but showed very low percentages of DNA binding with the other strains of Corynebacterium tested. Strain 42 Fukuya showed $63 \%$ DNA binding with 46 Hara, $30 \%$ with $C$. renale ATCC 19412, and very low percentages with the remaining strains.

In addition to the data presented here for strains 46 Hara and 42 Fukuya, further observations on these strains have been reported previously in the literature as follows.

Piliation was stable for both strains under various cultural conditions. Thick and long bundles of pili were characteristic of strain 46 Hara $(20,21)$. The purified pili of strain 46 Hara were found to be protein, to have a molecular weight of 19,000 , and to be composed of 20 amino acids (12). The partially purified pili of strain $42 \mathrm{Fu}$ kuya seemed to be primarily protein in nature. The pili of strains 46 Hara and 42 Fukuya were thermostable in morphology and antigenicity. The antigenicities of the pili of strain $46 \mathrm{Hara}$, strain 42 Fukuya, and a strain of $C$. renale were different from each other (13). Strain 42 Fukuya required thiamine, biotin, nicotinic acid, pantothenic acid, and pyridoxine as growth factors, and glutamic acid, valine, and isoleucine, and tryptophane as essential amino acids (2). Although the nutritional requirements of strain 46 Hara were not determined, organisms that were similar to this strain and that belonged to $C$. renale immunological type II required biotin, nicotinic acid, and $p$-aminobenzoic acid as growth factors, and glutamic acid, valine, and isoleucine as essential amino acids; thus they differed from strain 42 Fukuya in vitamin and amino acid requirements (2). Cells of strain 42 Fukuya were long, 1.5 to 5.0 times as long as normal cells, when grown in a minimal medium deficient in or with an excess of $\mathrm{Mg}^{2+}, \mathrm{Mn}^{2+}$, and $\mathrm{Cu}^{2+}$; they were long in the medium deficient in $\mathrm{Fe}^{2+}$ and short (coccoid form) in the medium with an excess of $\mathrm{Fe}^{2+}$. Cells of regular size were found in the minimal medium with $10 \mu \mathrm{g}$ of $\mathrm{Mg}^{2+}$ per ml, $10 \mu \mathrm{g}$ of $\mathrm{Fe}^{2+}$ per ml, $0.5 \mu \mathrm{g}$ of $\mathrm{Mn}^{2+}$ per $\mathrm{ml}$, or $0.5 \mu \mathrm{g}$ of $\mathrm{Cu}^{2+}$ per $\mathrm{ml}(3)$. Cells of strains 46 Hara and 42 Fukuya agglutinated trypsinized sheep erythrocytes (9) and attached to various tissue culture cells (10). The guanine-plus-cytosine $(\mathrm{G}+\mathrm{C})$ content of the DNA of strain 46 Hara was $59.8 \mathrm{~mol} \%$ and that of strain 42 Fukuya was $52.6 \mathrm{~mol} \%$ (11). In both strains, major cell wall sugars were arabinose, galactose, and glucose, and cell wall amino acids were alanine, glutamic acid, and meso-diaminopimelic acid; mannose was found in the cell wall of strain 46 Hara but not in that of strain 42 Fukuya (E. Honda and R. Yanagawa, Jpn. J. Vet. Res., in press). The purified type-specific antigen of strain 42 Fukuya contained arabinose, mannose, and glucose (17). Organisms which were similar to strain 46 Hara and which belonged to $C$. renale immunological type II were isolated from the urine and vagina in approximately $4 \%$ of healthy cows $(5,6)$ and caused cystitis and pyelonephritis occasionally; these organisms were much less virulent in cows (4) and in mice (16) than was $C$. renale. Organisms that were similar to strain 42 Fukuya and that belonged to $C$. renale immunological type III were found in many countries (18) and caused severe hemorrhagic cystitis (which often progressed to pyelonephritis) in cows without exception (4); the organisms were not isolated from healthy cows but were isolated from the prepuce in more than $90 \%$ of apparently healthy bulls, where they apparently do not cause any disturbance (7). They occasionally caused cystitis and pyelonephritis in mice when injected into the urinary bladder (16).

\section{DISCUSSION}

The observed morphological, cultural, and biochemical characteristics of strains 46 Hara 
TABLE 4. Characteristics in which there are strain differences

\begin{tabular}{|c|c|}
\hline Characteristic $^{a}$ & Strains $^{b}$ with positive reaction \\
\hline \multicolumn{2}{|l|}{ Cell morphology } \\
\hline Length $(<1 \mu \mathrm{m})$ & pt, $\mathbf{x}$ \\
\hline Length $(1-3 \mu \mathrm{m})$ & All strains except $\mathbf{m}, \mathbf{p t}, \mathbf{x}$ \\
\hline Length $(>3 \mu \mathrm{m})$ & m \\
\hline Length/width $(<1.5)$ & $\mathbf{x}$ \\
\hline 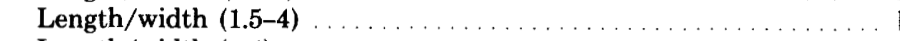 & b, hm, hg, k, n, pm, pl, pd, pt, r, s \\
\hline 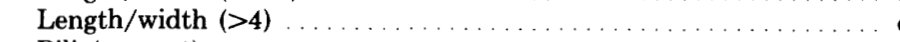 & $c, d, \mathbf{e}, \mathbf{m}, \mathbf{p y}$ \\
\hline$\ldots \ldots \ldots \ldots \ldots \ldots \ldots \ldots$ & All strains except $\mathbf{n}, \mathrm{pm}$ \\
\hline$\ldots \ldots \ldots \ldots \ldots \ldots \ldots \ldots \ldots$ & $\mathrm{c}, \mathrm{d}, \mathbf{k}, \mathrm{pl}, \mathrm{pd}$ \\
\hline Pili (thick bundle formation) & b, c, d, e, hg, k, m, pl, pd, pt, py, s, x \\
\hline Gram stain (not easily decolorized) & All strains except $\mathbf{n}$ \\
\hline \multicolumn{2}{|l|}{ Colony } \\
\hline Visible within $24 \mathrm{~h}$ at $37^{\circ} \mathrm{C}$ & $\mathrm{d}, \mathrm{e}, \mathrm{hg}, \mathrm{k}, \mathrm{pl}, \mathrm{pd}, \mathrm{pt}, \mathrm{r}, \mathrm{s}, \mathrm{x}$ \\
\hline Visible within $48 \mathrm{~h}$ at $37^{\circ} \mathrm{C}$ & All strains except $n, p m$ \\
\hline Visible within $24 \mathrm{~h}$ at $30^{\circ} \mathrm{C}$ & $\mathrm{d}, \mathrm{e}, \mathrm{hg}, \mathrm{k}, \mathrm{m}, \mathrm{pl}, \mathrm{pd}, \mathrm{pt}, \mathrm{r}, \mathrm{s}, \mathrm{x}$ \\
\hline Visible within $48 \mathrm{~h}$ at $30^{\circ} \mathrm{C}$ & All strains except py \\
\hline$\ldots \ldots \ldots \ldots \ldots \ldots$ & d, py \\
\hline$\ldots \ldots \ldots \ldots \ldots \ldots \ldots \ldots$ & All strains except $d$, py \\
\hline Nondiffusible pigment (off-white) $\ldots \ldots \ldots \ldots \ldots \ldots \ldots \ldots \ldots \ldots \ldots \ldots \ldots \ldots$ & b, c, d, hm, k, m, pm, pd, pt, py, s \\
\hline Nondiffusible pigment (yellow) $\ldots \ldots \ldots \ldots \ldots \ldots \ldots \ldots \ldots \ldots$ & $\mathbf{n}, \mathbf{p l}, \mathbf{r}, \mathbf{x}$ \\
\hline Nondiffusible pigment $($ pink) $\ldots \ldots \ldots \ldots \ldots \ldots \ldots \ldots \ldots \ldots$ & e, hg \\
\hline Growth on nutrient agar (without serum) & All strains except hm, py \\
\hline \multicolumn{2}{|l|}{ Growth in serum broth } \\
\hline Even turbidity .... & c, e, hg, k, m, pm, pl, pd, pt, py, r, s \\
\hline Flocculent turbidity & \\
\hline$\ldots \ldots \ldots \ldots \ldots \ldots$ & e, hg, pl, pd, pt, $x$ \\
\hline \multicolumn{2}{|l|}{ Temperature of growth in serum broth } \\
\hline Growth at $5^{\circ} \mathrm{C}$ for 40 days & $\mathbf{m}$ \\
\hline Growth at $41.5^{\circ} \mathrm{C}$ for 7 days & $c, e, h m, h g, p y, r, s$ \\
\hline \multicolumn{2}{|l|}{$\mathrm{pH}$ growth range in serum broth } \\
\hline Growth at initial pH 5.4 & b, d, e, hm, hg, pm, pt, py, r, s \\
\hline$\ldots \ldots \ldots \ldots \ldots \ldots \ldots \ldots \ldots \ldots \ldots$ & c, e, hg, k, pm, pl, pd, pt, py, r, s, x \\
\hline \multicolumn{2}{|l|}{ Heat resistance } \\
\hline Resistant to $54^{\circ} \mathrm{C}$ for $30 \mathrm{~min}$ & b, c, e, hg, pm, pl, pt, r, s \\
\hline Resistant to $56^{\circ} \mathrm{C}$ for $30 \mathrm{~min}$ & $\mathrm{~b}, \mathrm{hg}, \mathrm{pm}, \mathrm{pl}, \mathrm{pt}, \mathrm{r}$ \\
\hline \multicolumn{2}{|l|}{ Spontaneous agglutination in } \\
\hline $0.85 \%$ saline $(\mathrm{pH} 3.0)$ & b, c, d, pm, pl, pd, s, x \\
\hline $0.85 \%$ saline $(\mathrm{pH} 5.0)$ & b, c, d, hm, pm, pl, pd, $x$ \\
\hline $0.85 \%$ saline $(\mathrm{pH} 7.0)$ & pm, pd, $x$ \\
\hline \multicolumn{2}{|l|}{ Biochemical reactions: } \\
\hline Glucose, aerobic tube acid & All strains except pd \\
\hline Glucose, anaerobic tube acid & All strains except pd \\
\hline \multicolumn{2}{|l|}{ Acid from: } \\
\hline$\ldots \ldots \ldots \ldots \ldots \ldots \ldots \ldots$ & c, $\mathrm{d}$ \\
\hline 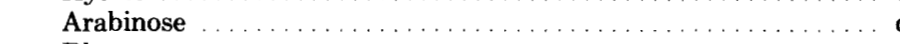 & d, pt, py \\
\hline 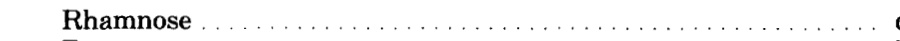 & d \\
\hline 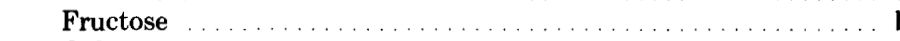 & b, c, d, hm, k, pl, pt, py, r, s, x \\
\hline$\ldots \ldots \ldots \ldots \ldots \ldots \ldots \ldots \ldots \ldots \ldots \ldots \ldots \ldots, c$ & d, pt, s, x \\
\hline 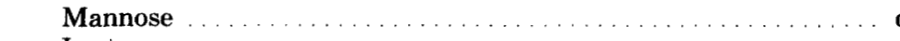 & $\mathrm{d}, \mathbf{k}, \mathrm{pl}, \mathrm{pt}, \mathrm{py}, \mathrm{r}, \mathrm{s}$ \\
\hline 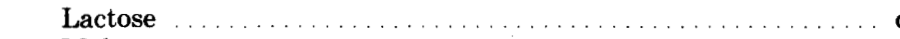 & d \\
\hline$\ldots \ldots \ldots \ldots \ldots \ldots \ldots \ldots \ldots \ldots \ldots$ & $\mathrm{c}, \mathrm{d}, \mathrm{k}, \mathrm{pl}, \mathrm{pt}, \mathrm{r}, \mathrm{s}$ \\
\hline$\ldots \ldots \ldots \ldots \ldots \ldots \ldots \ldots \ldots \ldots \ldots, \mathbf{c}$ & d, hm, py \\
\hline$\ldots \ldots \ldots \ldots \ldots \ldots \ldots \ldots \ldots \ldots, \mathbf{c}$ & $\mathrm{d}, \mathrm{k}, \mathrm{pt}, \mathrm{py}, \mathrm{s}, \mathrm{x}$ \\
\hline$\ldots \ldots \ldots \ldots \ldots \ldots \ldots \ldots \ldots$ & c, d, pl, pt, py, r, x \\
\hline 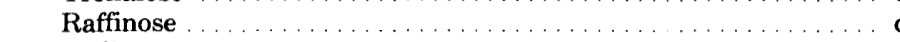 & $\mathrm{d}$, py \\
\hline 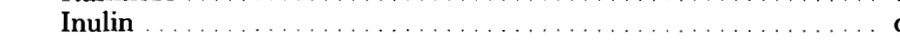 & d, hm, py \\
\hline$\ldots \ldots \ldots \ldots \ldots$ & $\mathrm{d}, \mathrm{k}, \mathrm{py}, \mathrm{x}$ \\
\hline$\ldots \ldots \ldots \ldots \ldots \ldots \ldots \ldots \ldots \ldots \ldots \ldots$ & c, d, hm, k, pl, pt, py, r, s \\
\hline$\ldots \ldots \ldots \ldots \ldots \ldots \ldots \ldots \ldots$ & c, d, k, pl, pt, py, s \\
\hline 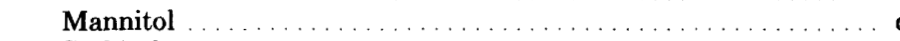 & d, py \\
\hline$\ldots \ldots \ldots \ldots \ldots \ldots \ldots \ldots \ldots \ldots$ & d, pt, py \\
\hline Inositol & d, py \\
\hline$\ldots \ldots \ldots \ldots \ldots \ldots \ldots \ldots \ldots \ldots$ c & d, py \\
\hline 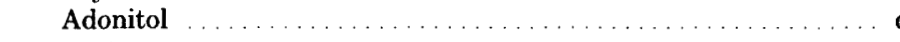 & d, py \\
\hline
\end{tabular}


TABLE 4. - Continued

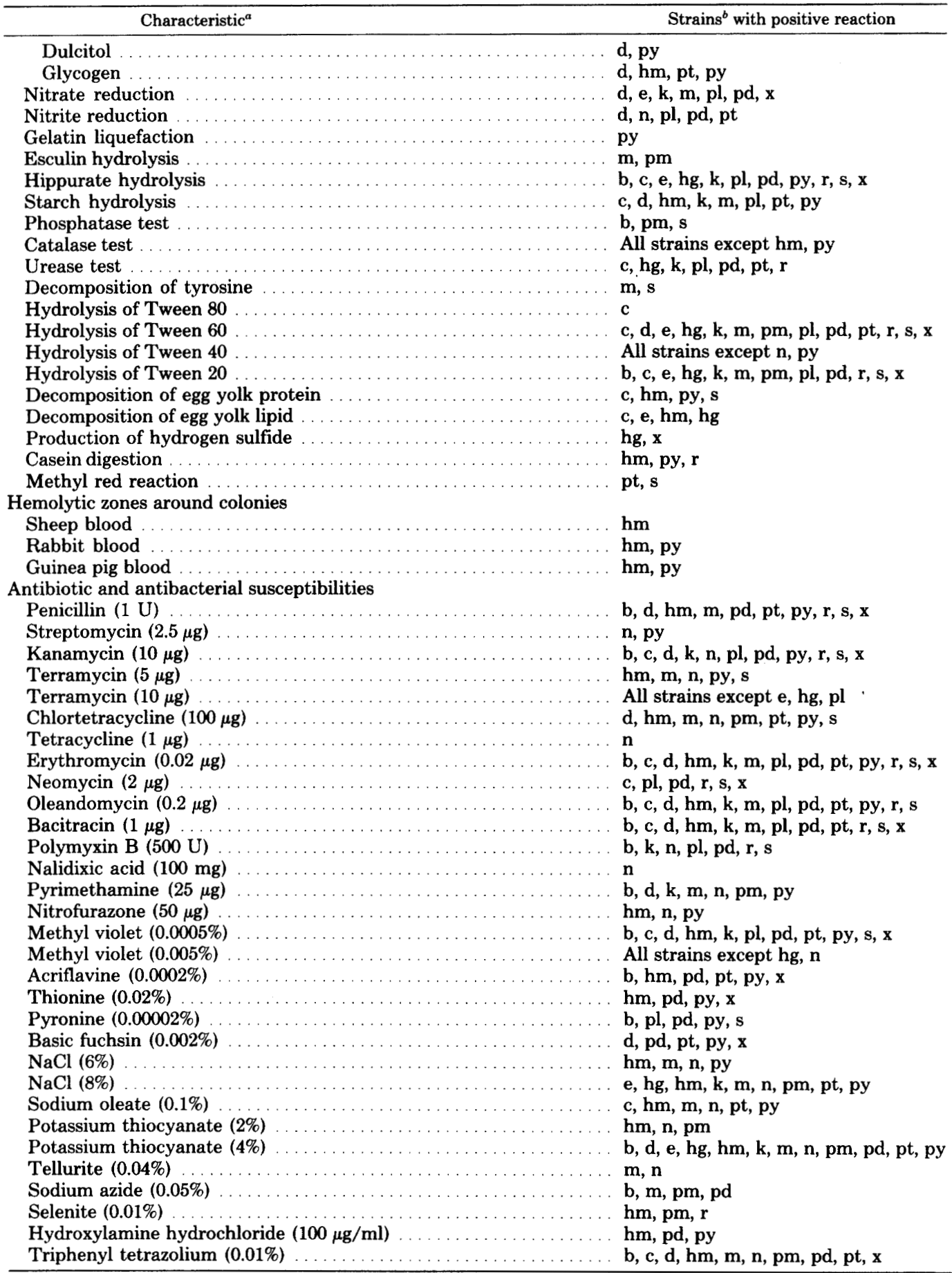

${ }^{a}$ Nutrient agar containing $5 \%$ calf serum was used as a basal medium.

${ }^{b}$ Symbols: b, $C$. bovis ATCC 7715; c, C. cystitidis strain 42 Fukuya; d, C. diphtheriae ATCC 19409; e, C. equi ATCC 6939; hm, C. haemolyticum ATCC 9345; hg, C. hoagii ATCC 7005; k, C. kutscheri ATCC 15677; m, C. murisepticum ATCC 21374; n, C. nephridii ATCC 11425; pm, C. paurometabolum ATCC 8368; pl, C. pilosum strain 46 Hara; pd, C. pseudodiphtheriticum ATCC 10700; pt, C. pseudotuberculosis ATCC 19140; py, C. pyogenes ATCC 19411; r, C. renale ATCC 19412; s, C. striatum ATCC 6949; x, C. xerosis ATCC 373. 
TABLE 5. DNA homologies of strains of Corynebacterium species that are parasitic on or pathogenic to animals ${ }^{a}$

\begin{tabular}{|c|c|c|}
\hline \multirow{2}{*}{ Test strain } & \multicolumn{2}{|c|}{$\begin{array}{l}\text { DNA homology } \\
\text { with: }\end{array}$} \\
\hline & $\begin{array}{l}\text { Strain } 46 \\
\text { Hara }\end{array}$ & $\begin{array}{c}\text { Strain } 42 \\
\text { Fukuya }\end{array}$ \\
\hline 46 Hara & $100^{c}$ & 63 \\
\hline 42 Fukuya & 60 & $100^{c}$ \\
\hline C. renale ATCC 19412 & 40 & 30 \\
\hline C. equi АТCC 6939 & 21 & 16 \\
\hline C. murisepticum ATCC 21374 & 18 & 8 \\
\hline C. pyogenes ATCC 19411 & 17 & 13 \\
\hline C. striatum ATCC 6949 & 11 & 7 \\
\hline C. kutscheri ATCC 15677 & 10 & 5 \\
\hline C. haemolyticum ATCC 9345 & 10 & 9 \\
\hline C. pseudotuberculosis ATCC 19410 & 9 & 7 \\
\hline C. diphtheriae ATCC 19409 & 8 & 6 \\
\hline C. xerosis ATCC 373 & 8 & 17 \\
\hline C. paurometabolum ATCC 8368 & 8 & 5 \\
\hline C. hoagii ATCC $7005 \ldots$ & 8 & 13 \\
\hline C. pseudodiphtheriticum ATCC 10700 & 7 & 9 \\
\hline C. nephridii ATCC 11425 & 3 & 4 \\
\hline C. bovis ATCC 7715 & 2 & 3 \\
\hline $\begin{array}{l}\text { 'The labeled DNAs of strains } 46 \text { Hara } \\
\text { used as references. } \\
{ }^{b} \text { Expressed in terms of percentage of } \\
\text { gous reactions related to those of the h } \\
{ }^{c} \text { The radioactivities (counts per minut } \\
\text { reactions were } 474 \text { (strain } 46 \text { Hara) and } 70\end{array}$ & $\begin{array}{l}\text { and } 42 \mathrm{Fu} \\
\text { binding fo } \\
\text { omologous } \\
\text { te) of the } \mathrm{h} \\
05 \text { (strain } 4\end{array}$ & $\begin{array}{l}\text { kuya were } \\
\text { heterolo- } \\
\text { reactions. } \\
\text { mologous }\end{array}$ \\
\hline
\end{tabular}

and 42 Fukuya are consistent with those of the corynebacteria cited in Bergey's Manual (15) as parasites and pathogens of humans and other animals. From the results of the numerical analysis and DNA homology studies, we regard strains 46 Hara and 42 Fukuya as belonging to two new species, for which we propose the names Corynebacterium pilosum (pi.lo'sum. L. adj. pilosus having much hair; intended to mean having many pili) and Corynebacterium cystitidis (cys.ti'ti.dis. Gr. n. cyst bladder; M.L. n. cystitis cystitis; M.L. gen. n. cystitidis of cystitis), respectively. The type strain of $C$. pilosum is 46 Hara (= ATCC 29592); the type strain of $C$. cystitidis is 42 Fukuya (= ATCC 29593). Because at present only a single strain of each of these species is known, the descriptions given above for the strains also serve as the descriptions of the species.

Differential characteristics. Table 6 contains a list of properties that are useful in differentiating $C$. pilosum and $C$. cystitidis from the other species of Corynebacterium that are parasitic on or pathogenic to humans and/or other animals.

TABLE 6. Characteristics useful in differentiating C. pilosum and C. cystitidis from other species of Corynebacterium that are parasitic on or pathogenic to humans and other animals

\begin{tabular}{|c|c|c|c|c|c|c|c|c|c|c|c|c|c|c|c|c|c|}
\hline \multirow[b]{2}{*}{ Characteristic $^{a}$} & \multicolumn{17}{|c|}{ Results obtained with: } \\
\hline & 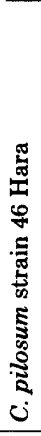 & 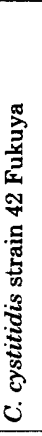 & 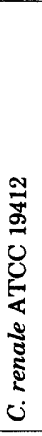 & 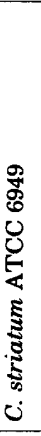 & 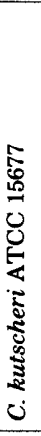 & 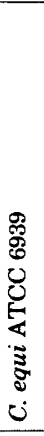 & 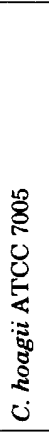 & 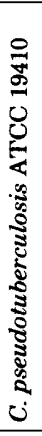 & 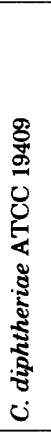 & 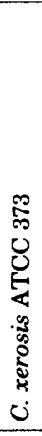 & 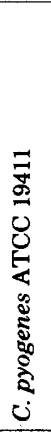 & 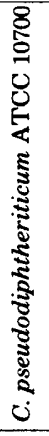 & 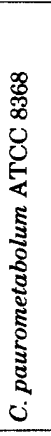 & 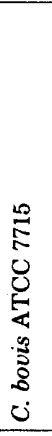 & 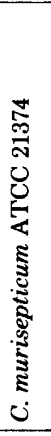 & 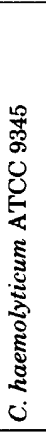 & 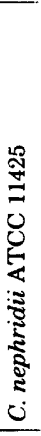 \\
\hline & + & + & - & - & + & - & - & - & + & - & - & + & - & - & - & - & - \\
\hline dium & + & + & + & + & + & + & + & + & + & + & + & - & + & + & + & + & + \\
\hline um broth & - & + & - & - & - & - & - & - & + & - & - & - & - & - & - & - & - \\
\hline in serum broth & - & - & - & + & + & - & - & + & + & + & + & - & - & - & - & - & - \\
\hline & + & + & + & - & + & - & + & + & - & - & - & + & - & - & - & - & - \\
\hline & - & - & + & - & - & - & - & - & - & - & + & - & - & - & - & + & - \\
\hline & + & - & - & + & + & + & - & - & + & + & - & + & - & - & + & - & - \\
\hline & - & + & - & - & - & - & - & - & - & - & - & - & - & - & - & - & - \\
\hline & + & + & - & - & + & - & - & + & + & - & + & - & - & - & + & + & - \\
\hline & - & - & - & - & - & - & - & - & - & - & + & - & - & - & - & - & - \\
\hline tion & - & - & - & + & - & - & - & - & - & - & - & - & - & - & + & - & - \\
\hline & - & - & - & - & - & - & - & - & - & - & - & - & + & - & + & - & - \\
\hline$m$ & - & + & + & + & + & - & - & + & + & + & + & + & + & + & + & + & $T$ \\
\hline acid per $\mathrm{ml}$ & - & - & - & - & - & - & - & - & - & - & - & - & - & - & - & - & + \\
\hline oleate ......... & - & + & - & - & - & - & - & + & - & - & + & - & - & - & + & + & + \\
\hline & - & - & - & - & + & + & + & + & - & - & + & - & + & - & + & + & + \\
\hline & - & - & - & - & + & + & + & + & + & - & + & + & + & + & + & + & + \\
\hline 5.4) & - & - & + & + & - & + & + & + & + & - & + & - & + & + & - & + & - \\
\hline
\end{tabular}

Acid from glucose in serum O-F medium

Acid from xylose in serum broth

Acid from sucrose in serum broth

Urease

Caseinase

Nitrate reduction

Tween 80 hydrolysis

Starch hydrolysis

Gelatin liquefaction

Tyrosine decomposition

Esculin hydrolysi

Susceptibility to:

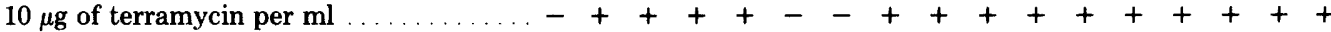

$100 \mu \mathrm{g}$ of nalidixic acid per $\mathrm{ml}$

$0.1 \%$ sodium oleate

$8 \% \mathrm{NaCl}$

4\% potassium thiocyanate
rowth in serum broth (pH 5.4$)$

${ }^{a}$ Media containing $5 \%$ calf serum were used for all tests with the exception of urease activity. 


\section{ACKNOWLEDGMENT}

We thank Yumiko Fukagawa for excellent technical assistance.

\section{REPRINT REQUESTS}

Address reprint requests to: Dr. Ryo Yanagawa, Department of Hygiene and Microbiology, Faculty of Veterinary Medicine, Hokkaido University, Sapporo 060, Japan.

\section{LTERATURE CITED}

1. Cowan, S. T. 1974. Manual for the identification of medical bacteria, 2nd ed. Cambridge University Press, Cambridge.

2. Hirai, K., and R. Yanagawa. 1967. Nutritional requirements of Corynebacterium renale. Jpn. J. Vet. Res. 15:121-134.

3. Hirai, K., S. Shimakura, and R. Yanagawa. 1969. Minimum medium for Corynebacterium renale and filamentous growth due to deficiency or excess of inorganic ions. Jpn. J. Vet. Sci. 31:149-159.

4. Hiramune, T., S. Inui, N. Murase, and R. Yanagawa. 1971. Virulence of three types of Corynebacterium ren ale in cows. Am. J. Vet. Res. 32:236-242.

5. Hiramune, T., T. Kume, N. Murase, and R. Yanagawa. 1970. Typing of Corynebacterium renale isolated from cattle in a herd with persistent pyelonephritis. Jpn. J. Vet. Sci. 32:81-85.

6. Hiramune, T., N. Murase, and R. Yanagawa. 1970. Distribution of the types of Corynebacterium renale in Japan. Jpn. J. Vet. Sci. 32:235-242.

7. Hiramune, T., M. Narita, N. Murase, and R. Yanagawa. 1975. Distribution of Corynebacterium renale among healthy bulls with special reference to inhabitation of type III in the prepuce. Natl. Inst. Anim Health Q. 15:116-121.

8. Honda, E., and R. Yanagawa. 1973. Deoxyribonucleic acid homologies among three immunological types of Corynebacterium renale (Migula) Ernst. Int. J. Syst. Bacteriol. 23:226-230.

9. Honda, E., and R. Yanagawa. 1974. Agglutination of trypsinized sheep erythrocytes by the pili of Coryne bacterium renale. Infect. Immun. 10:1426-1432.

10. Honda, E., and R. Yanagawa. 1975. Attachment of Corynebacterium renale to tissue culture cells by the pili. Am. J. Vet. Res. 36:1663-1666.

11. Kumazawa, N., and R. Yanagawa. 1969. DNA base compositions of the three types of Corynebacterium renale. Jpn. J. Vet. Res. 17:115-120.

12 Kumazawa, N., and R. Yanagawa. 1972. Chemical properties of the pili of Corynebacterium renale. Infect. Immun. 5:27-30.

13 Kumazawa, N., and R. Yanagawa. 1973. Comparison of the chemical and immunological properties of the pili of three types of Corynebacterium renale. Jpn. J. Microbiol. 17:13-19.

14. Lessel, E. F., and J. G. Holt. 1970. In W. R. Lockhart and J. Liston (ed.), Methods for numerical taxonomy. American Society for Microbiology, Bethesda, Md.

15. Rogosa, M., C. S. Cummins, R. A. Lelliott, and R. M. Keddie. 1971. Coryneform group of bacteria, $p$. 599-617, In R. E. Buchanan and N. E. Gibbons (ed.), Bergey's manual of determinative bacteriology, 8th ed. The Williams \& Wilkins, Co., Baltimore.

16. Shimono, E., and R. Yanagawa. 1977. Experimental model of Corynebacterium renale pyelonephritis produced in mice. Infect. Immun. 16:263-267.

17. Shinagawa, M., and R. Yanagawa. 1970. Characterization of the type specific antigen of three types of Corynebacterium renale. Jpn. J. Vet. Res. 18:75-82.

18. Yanagawa, R. 1975. A numerical taxonomic study of the strains of three types of Corynebacterium renale. Can. J. Microbiol. 21:824-827.

19. Yanagawa, R., H. Basri, and K. Otsuki. 1967. Three types of Corynebacterium renale classified by precipitin reaction in gels. Jpn. J. Vet. Res. 115:111-120.

20. Yanagawa, R., and K. Otsuki. 1970. Some properties of the pili of Corynebacterium renale. J. Bacteriol. 101:1063-1069.

21. Yanagawa, R., K. Otsuki, and T. Tokui. 1968. Electron microscopy of fine structure of Corynebacterium renale with special reference to pili. Jpn. J. Vet. Res. 16:31-38. 